\title{
Administration of Physical Education and Sports in Nigeria
}

\author{
Alla J. B. \\ Head, Department of Physical and Health education, \\ Obafemi awolowo University Ile, Osun state, Nigeria. \\ Tel: 234-80-3560-2629 E-mail: Joe_alla@yahoo.com
}

Ajibua M. A (Corresponding author)

Coordinator, Sports Centre,

Federal University of Technology, Akure, Ondo State, Nigeria

Tel: 234-80-3814-2303 E-mail: alayodeajibua@gmail.com

Received: January 24, 2011

Accepted: February 1, 2012 Published: March 1, 2012

doi:10.5539/hes.v2n1p88

URL: http://dx.doi.org/10.5539/hes.v2n1p88

\begin{abstract}
Physical Education is a vital part of total education. It is that process of education that concerns physical activities, which develop and maintain human body. The attainment of its goals depends on its administrative control structure more than any other thing. Physical Education Curriculum is entrenched in the National Policy on Education and thus, it is taught at all levels of educational development in Nigeria. The administration of Physical education is divided into four parts i.e. 6-3-3-4. However, it has not received the required attention from the government partly because of the economic situation in the country. This has greatly affected its growth and development. It is believed in some quarters that despite the negative attitude of the government that Physical Education can survive and still attain its goals in Nigeria with efficient and effective organizational structure. Therefore, this study is proposing an organizational structure model for achieving developmental goal of Physical Education in Nigeria.
\end{abstract}

Keywords: Education system, curriculum, national policy on education, intramural, interscholastic.

\section{Introduction}

Physical Education is viewed by Ajala, Amusa and Sohi (2001) as a vital part of Education. It contributes to the general programme of education including the development of health, physical welfare, and recreation. Although not a new field, Physical Education continues to receive several definitions. Adisa (2010) said that Physical Education is that process of education that concerns physical activities, which develop and maintain human body. The attainment of its objectives depends to a great extent on the leadership responsible for its direction. He also said that many nations have used it to train their youths. In order words, Physical Education is supposed to begin at childhood.

Akintunde, (2001) and Ogundairo, 2002) said that Physical Education is that phase of the total process of education that is concerned with the development and utilization of the individual's voluntary purposeful movement capabilities and which is directly related to mental, emotional, social and physical responses. This definition asserted that the school programme of Physical Education consists a specialized learning environment, characterized by many planned condition and stimuli specifically intended to induce or provide opportunities for physical, social, emotional, intellectual and other beneficial responses through which the student may become changed, modified or educated in desirable ways as approved by the society. As a result, Physical Education has been accepted as an essential educational experience in which all pupils/students engage regularly throughout elementary, secondary and higher education programme.

The acceptance of this definition in Nigeria will imply two things. Firstly, that since it is an experience limited to the school setting, many Nigerian children will be denied of it and consequently be denied of the virtues accruing from the experiences. It means too that many people in the country may lack those things that Physical Education gives since the society has entrusted that role to that aspect of education. Secondly, Nigeria will have to reappraise her educational philosophy in an attempt to provide Physical Education its own place (a core subject and co-curricular activity) in the total education of the child. By this, the few opportuned children will be able to go through these 
experiences while in school. Nigeria will also have to provide opportunities for both normal and handicapped children to go to school through her Universal Basic Education Policy. By this, each child in the country will benefit from every opportunity Nigerian society can offer.

The big question is, has Physical Education not been entrenched into the educational philosophy in Nigeria? Of course, it is clearly stated in the National Policy of Education (Revised Edition, 2004) the need to promote the emotional, physical and psychological health of all children through Physical Education. The problem is, the same government that includes it has not seen to its widespread. In other words, the government has accepted it in principle but not in practice. It is possible that Physical Education is being enforced in Federal Secondary Schools. Again, to what extent is this happening?

Physical Education Curriculum is entrenched in the National Policy on Education and thus, it is taught at all levels of educational development in Nigeria. The administration of Physical Education is divided into four parts i.e. 6-3-3-4. However, it has not received the required attention from the government partly because of the economic situation in the country. This has greatly affected its growth and development. It is believed in some quarters that despite the negative attitude of the government, that Physical Education can survive and still attain its goals in Nigeria with efficient and effective organizational structure. Therefore, this study is proposing an organizational structure model for achieving developmental goal of Physical Education in Nigeria.

\section{Administration of Physical Education and Sports in the Schools}

Lafinhan, (2002) said that Physical Education is part of the students' total education at elementary school, middle school, secondary school, college and university levels (6-3-3-4) i.e. 6 years for elementary, 3 for junior secondary school, 3 for senior secondary school and 4 for Tertiary institution. And these progress sequentially. At each level there is a particular organizational structure which is designed to assist in achieving a particular goal.

\subsection{Elementary}

This is referred to as education given in an institution for children aged 6- 11 years plus. Primary Education in Nigeria is compulsory, universal and free. All the subjects in the primary education curriculum including Physical and Health education are offered as core-subjects (National Policy on Education, 2004). Between these ages, the emphasis is to create an atmosphere of fun and enjoyment that will attract and develop the pupil affection to wanting to continue in sport. The Physical Education activities are to enable the pupils to use his body in different ways and at the same time gain control over his body in space (Alla and Olorunsola, 2008). The proposed organizational structure is shown in fig. 1 below.

In Nigeria, there is no Physical Education Specialist in the elementary school unless in private schools. The district consultant (inspector of education in Nigeria) who is a Physical Education specialist periodically advises the elementary classroom teacher. A district consultant however, may or may not be provided when there is a department of Physical Education. The elementary school level includes Kindergarten through eight grade or sixth grade as the case may be. At this level, many schools have changed from a traditional curriculum of self-contained classrooms to open or non-graded classes and from less emphasis on low-organized games, relays and combative skills to more emphasis on rhythms and movement education. Physical Education at this level is scheduled for 30 minutes twice a week. The teacher's schedule ranges from $8-10$ periods daily. Boys and girls in grades one through six come to the field as a heterogeneous group (co-educational) of about $20-30$ pupils in one class. Pupils are offered a broad range of activities that allow them to experience a variety of skills (Adeniji, 2007).

Physical Education is not enforced in all the elementary schools in Nigeria. Where it is enforced, it is not usually formally organized. Though many schools may insert it on the Time Table, teachers do not usually consider it very serious. The problem might be due partly to the fact that the system has not formally stressed it or school administrators have not agreed or admitted it into the school system (Mgbor, 2006).

\subsection{Secondary Schools}

\subsubsection{Junior High School}

Secondary School Education is the form of education children receive after primary education and before the tertiary level. The broad goal of secondary education is to prepare the individual for useful living within the society and higher education. It is also indicated in the National Policy on Education that the Junior Secondary shall be both pre-vocational and academic. It shall be tuition free, universal and compulsory. Physical Education at this level is placed as a non-vocational elective. However, some states in the country make it compulsory elective for Junior Secondary School students. The curriculum contents appear similar for the three levels except that in JSS II and III there is the inclusion of career guidance in Physical and Health Education. 
In many schools in Nigeria, Physical Education is usually a section under the sciences. Generally, a Physical Education teacher in this level teaches six to eight class periods per day and each period is from 45 to 50 minutes in lengths and contact period with each class ranges from two or three times per week with about 30 to 50 students in a class.

The need of students at this level is met through individual and team sports. Also opportunity for competition is provided through intramural and inter-scholastic meetings. These programmes are regarded as integral part of the Physical Education programme. Supervision of these programmes is included in the general teaching assignment.

\subsubsection{Senior High School}

The Senior Secondary School is recognized to be comprehensive with a core-curriculum designed to broaden pupils' knowledge and out-look (National Policy on Education, 2004). Physical and Health Education is offered as non-vocational elective options. Since this stage does not come under the National Basic Education Concept, the Federal Government appears silent about developing its curriculum for secondary schools. Physical education teachers, however, use the syllabus prepared by the West African Senior School Certificate Examination (WASSCE).

\subsubsection{College and University}

According to Fordham and Leaf (1978), a college can differ from a university in title, organizational structure, size and curriculum. A college is usually organized into divisions, schools and departments. For example, a college has the division of liberal arts and sciences that contain the school of education in which there is a department of Physical Education. A university includes colleges, divisions, schools and departments. For instance, at a University there is the college of Health, Physical Education and Recreation, which includes the division of athletics and department of Physical Education. In the University, students are of different backgrounds, experiences, interests, needs and goals. Students may obtain bachelors, masters or doctorate degrees.

At this stage, students pursuing bachelor's degree may enroll in Physical Education to meet a requirement or as an elective, but medical reasons, military service, age or athletic participation may serve to exempt students form required Physical Education. Here, also there are general programmes for those not majoring in Physical Education and Professional programme for those majoring in Physical Education. In Fig. 3 below is the organizational structure of Physical and Health Education of College/University P.E according to Forham and Leaf, (1978).

Where Physical Education is separated from Sports Administration, sports (Intramural and Interscholastic) rests on the Sports Council and its Director has direct communication link with the Vice-Chancellor. In a recent study conducted by Olorunsola and Alla (2005), four models of sports management were observed in Nigeria Universities Model - 1 Sports Committee Management; Model 2 Sports Council or Sports Committee Management; Model 3 Sports Council which has access to the Vice Chancellor through the Dean of Student Affairs and Model 4 - Sports Council which has direct access to the Vice-Chancellor.

Apart from the sporting activities that are being organized on individual College or University basis, there are the inter-collegiate sports called Nigeria University Games Association (NUGA), Nigeria Polytechnic Games Association (NIPOGA) and Nigeria Colleges of Education Games Association (NACEGA). Each has its own governing body. NUGA is being governed by the NUGA Council, which is made up of 3 representatives (Chairman Sport Council, Director of Sports and Students' Union Director of Sports) of member Universities and the secretariat is based at the National University Commission (NUGA, 2000). The Universities host inter-collegiate sporting activities in rotation. It is being financed by subvention from member Universities and grants from the government through the Committee of the Vice-Chancellor (CVC). It is a bi-annual affair (Akindutire, 2002). Good athletes from the NUGA Games are usually selected to represent the country in African University Games (FASU) and International University Games (FISU).

In an attempt to find out some of the factors affecting performance in Nigerian Universities Sports, Ajayi, Ajibua and Momoh (2009) and Ojeaga, (2010) discovered among other things, pattern of sports administration, facilities, personnel and intramural and extramural programmes.

Ojeaga, (2010) study revealed four (4) patterns of sports administration in Nigerian Universities:

a) Sports and Physical Education under one department or Institute - Universities of Nigeria, Nsukka, University of Ilorin and Ife, Ile-Ife.

b) Sports administration under the Sports Council - Universities of Ibadan, University of Benin, University of Lagos, The Federal University of Technology, Akure.

c) Sports administration under the Registry - Ahmadu Bello University.

d) Sports administration under the Dean Students' Affairs- University of Agriculture, Abeokuta. 
The study revealed that sports administrators in Nigerian Universities agreed that there should be a separate administration for Physical Education and Sports because putting both under one administration makes the process tedious and cumbersome. Specifically, there is the tendency of neglecting one aspect in preference to the other depending on the priority area of the Head of Department or the Director of the Institute. Though, the two sections are to operate separately, the academic staff of the Department of Physical Education should be involved in decision - making in the Sports Council and also be allowed to expose the athletes to researches. It is actually reasoned that as University research hospitals serve as practicing laboratories to lecturers at the College of Health Sciences, Sports section in the Universities should be the same for teachers of the Department of Physical Education. When this is followed, there seems to be positive result in University sports.

Olorunsola and Alla (2001), Ajayi, Ajibua and Momoh, (2009) and Ojeaga, 2010 found out that the factors that contribute to poor performance of athletes in Universities in Nigeria were unavailability of professional coaches, poor orientation of students, lack of facilities, and poor sports management practice. It was also discovered that the universities that operated healthy intramural and extramural programmes also has good results in NUGA games. In other words, if those factors are adequately catered for, there may be improvement on the standard of sports in Nigeria Universities.

\section{Administration of Sports in Nigeria}

Sports in Nigeria was initially managed by the Nigeria Olympic Sports Council. This council was basically meant for International Competitions and particularly the Olympic games. With time the Nigeria Olympic Council was found to be lacking the necessary competency for administering all the local sports now being played. Hence, this council gave way to the National Sports Council which came into being in 1962 in an attempt to solve the disintegrating problems that faced the Nigeria Football Association (NFA) and the Amateur Athletic Association of Nigeria (Reports on the activities of the Minster of Sports and the Sole Administration of National Sports Commission).

Although the Federal government made funds available to the Council to meet its need, there was no legislative provision for its existence until August 1971 as published in the Official Gazette No. 41, Volume 58 of August 12 1971 when by decree No. 34 the then Federal Military Government constitutionally set a body up and renamed it National Sports Commission 1984).

The revised Act establishing the Commission requires it to operate through three standing committees: Finance and general administration, Sports development, and stadia and physical facilities.

\subsection{Function of the National Sports Commission as in Act No. 34}

a) To encourage the development and organization of and participation in sports in Nigeria;

b) To coordinate and integrate efforts to raise the standard of performance in sports through Nigeria;

c) In all International relations affecting sports the commission has the sole right to make on behalf of State Sports Councils, any necessary arrangements for competitions technical assistance, recruitment of coaches and any such other matters as the commission may think fit;

d) To promote in co-operation with other sports bodies or sports groups, the physical fitness and general well being of all persons in Nigeria;

e) To organize or assist financially on otherwise the participation in sports at inter-state, national and international levels;

f) To train Nigerians to become sportsmen and instructors in sports;

g) To conduct and encourage research into all matters relating to sports;

h) To promote and maintain sports centers and facilities for training of Nigerians as instructors and organizers of sports;

i) To ensure the participation of all sportsmen where required in inter-state, national or international competition; and

j) To maintain every stadium owned or controlled by the Federal government and direct all activities relating thereto.

The Commission sets up the National Sports Associations. These Associations are technically responsible for the administration and organization of sports on a national basis. The National Sports Commission is empowered to encourage and coordinate the efforts of all sporting organizations in order to achieve efficient use of all the resources generated by and made available to sports at national and international levels. Hence, the National Sports 
Commission communicates directly with the National Sports Associations (see fig. 4 for the Organizational structure of National Sports Commission in Nigeria).

Another Sports body is the Nigeria Olympic Committee. The National Sports Commission allows the National Sports Associations and the Nigeria Olympic Committee to deal directly with their international counterparts in order to ensure that Nigeria is worthily represented, but the National Sports Commission has the responsibility to the Federal Government to ensure that these organizations are carrying out their activities with Federal Government of Nigeria's aspirations and integrity (Ikhioya, 2010).

The present national administrative set-up for sports now recognizes sports management through the National Sport Commission. The Director-General under the Sports development unit administers national sports through the Sports Associations.

The State Sports Council serves in each State in such capacity previously occupied by the National Sports Commission at the National level. Communications are direct between the National Sports Commission and State Sports Council. Any official matter concerning any particular sport in a state goes from the State Sport Councils through National Sports Commission to the National Sports Associations.

There are other National Sports groups whose national events are closed to their kith and kin e.g. Nigeria School Sports Federation (NSSF), Nigeria Police Sports, and Nigerian Colleges of Agriculture Games Association (NACAGA). These groups communicate with the National Sports Commission (Ojeaga, 2010).

\section{Conclusion}

The arrangement put in place by the government for sports seems to be facing challenges. Organization of Sports internally has not been achieving satisfactorily national sports objectives (Ajayi, Ajibua and Momoh, 2010). Nigeria in the recent past has not performed well at international sports competitions. The Green Eagles failed to attain the ticket for 2006 World Soccer. The medals table during the recent past Olympics and Commonwealth games for Nigeria was discouraging (Ajibua and Momoh, 2010). It is the time the government reassesses its sports management policy. Sports must be given to the professionals to manage. More importantly, there is the need to have a research-based data for sports management. The first and immediate step may be to inaugurate a strong panel to look into ways to move sports forward in Nigeria.

\section{References}

Adeniji, E.O (2007). 9-Year Basic Basic Education Curriculum (Physical Education) for Primaries 1-3, 4-6 and JSS 1, Nigerian Education Research and Development Council.

Adisa, O. (2010). Underdevelopment of Sport in Nigeria: A Need for Physical Education Curriculum

Ajala ,J. A, Amusa, L.O. and Sohi, A.S (2002). Physical Education. Macmillan Publishers, Lagos.

Ajayi, M.O., Ajibua, M.A, and Momoh, D.M. (2009). Enhancing Nigerian brand through University Games. Journal of Physical Education and Research, Vol. XIII, No II, pp. 2012-2020.

Ajibua M.A. and Momoh, D.M. (2010). Total Quality Management: A Requirement for Rapid Sports Development in Nigeria. In Ogundele, B.O., Optimal Health Performance: Human Movement Education in the $2{ }^{\text {st }}$ Century, $a$ book of reading on Professor V.C. Igbanugo of the Department of Human Kinetics, University of Ibadan.

Akindutire. O. (2002). Sport Administration. In Ojeme, E.O Iyawe, V.I, Oshodin O.G., Career Prospects in Physical and Health Education. Centre for Motor Research and Resources Development for Africa (CMRRD).

Akintunde, P.G. (2001). Administration and Organization of Physical and Health Education, Sport and Dance, $\left(1^{\text {st }}\right.$ ed $)$, YEM Books, Ibadan.

Alla, J.B. and Olorunsola, H.K (2008). Physical Education Curriculum and its implementation in Nigeria Schools. Fourth International Council for Health, Physical Education, Recreation, Sport and Dance (ICHPER. SD) Africa Regional Congress, 14-17, pp172-179.

Diversification. In Ogundele, B.O. Optimal Health Performance: Human Movement Education in the $21^{\text {st }}$ Century, a book of reading on Professor V.C. Igbanugo, pp. 298-213.

Education in the Olympic Movement (A perspective in Olympism). Nigerian National Olympic Academy Publishers pp. 11-41

Fordham, S.L and Leaf, C.A. (1978) Physical Education and Sports._ An introduction to alternative careers; John Wiley \& Sons New York, pp. $29-44$.

Ikhioya, O.S.A (2010). Understanding Fundamental of Olympic 
Mgbor, M.O. (2006). Issues and future direction of physical education in Nigeria Retrieved Feb., $15^{\text {th }}$ from: http://www..The Sage Online Journal.Org.

National Policy on education, 2004 revised Ed.

NUGA (2000). Draft Review of Constitution. Nigerian University Games Association.

Nwankwo, E.I (2002). The role of Research and Continuous Education in Professionalization of Sports Management in Nigeria. 2nd Seminar of the Nigeria Association for Physical Education held in Asaba, Delta State, Nigeria

Ogundairo, D. (2002). Essentials of Physical Education. ( $1^{\text {st }}$ ed.) Extension Publication Limited, Lagos, pp.1-10

Ojeaga, A.P. (2010). Sport Development in Tertiary Institutions in Nigeria. A paper present at a seminar for Coaches and Sports Administrators in tertiary institutions in Nigeria organized by Centre for Research and Development.

Ojeme, E.O (2000). Nigeria's Vision 2010: A New Impetus for curriculum change in Nigeria.In Ojeme, E.O, Iyawe, V.O and Oshodin O.G., 2000. Career prospects in Physical and Health Education. Centre for Motor Research and Resources Development for Africa (CMRRD), Benin City.

Olorunsola, H.K. and Alla, J.B. (2001). Challenges facing Sports Participation and Management in Nigeria Universities, Ife Journal of Educational Studies, Vol. 9 No. 1 pp 63-67.

Olorunsola, H.K. and Alla, J.B. (2005) Status of Sports Management and Promotion in Nigeria Universities, Ife Journal of Curriculum Studies and Development, Vol. 2 No. 2, pp. $74-81$.

Report on the activities of the NSC submitted by the Minister of Sports and Sole Administrator of NSC, 1984).

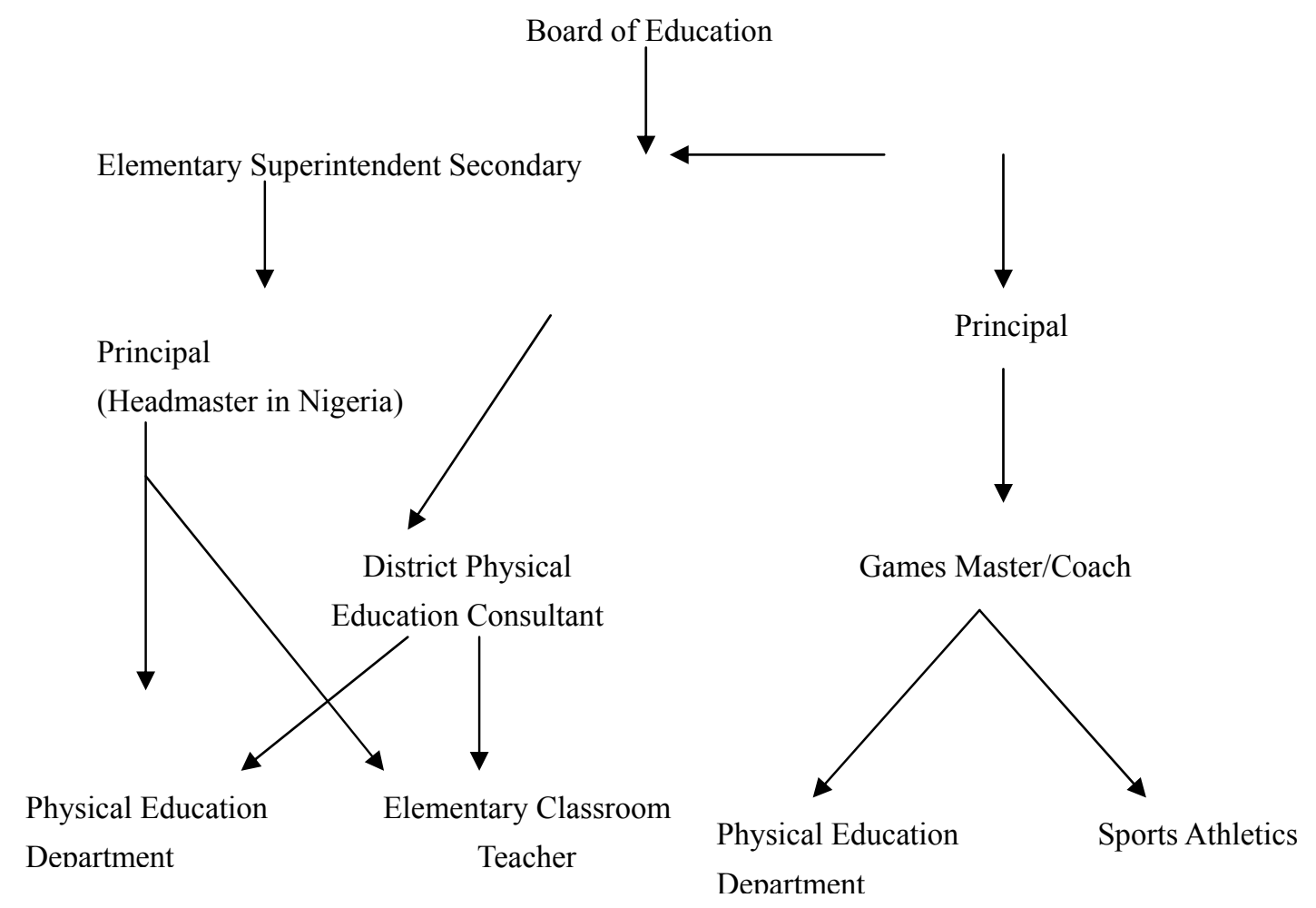

Figure 1. Proposed Organizational Structure of Elementary and Secondary School Physical Education 
State Board of Higher Education

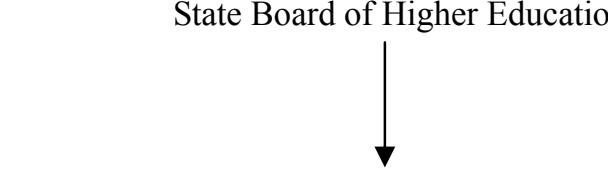

College or University Board of Reagents

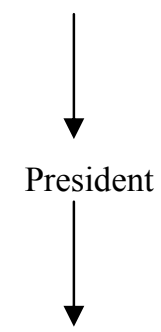

Vice President

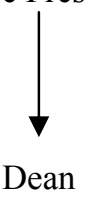

(College of Health, P.E. and Recreation)<smiles>C[13CH2]</smiles>

Division Head

(Division of Health, P.E. and Recreation)<smiles>[CH]1CC1</smiles>

Director

(School of Health, P.E. and Reaction)<smiles>C[13CH2]</smiles>

Department Head

(Department of Health, P.E. and Recreation)

Sources: Forham and Leaf ;1978

Figure 2. Organizational Structure of College/University P.E. 


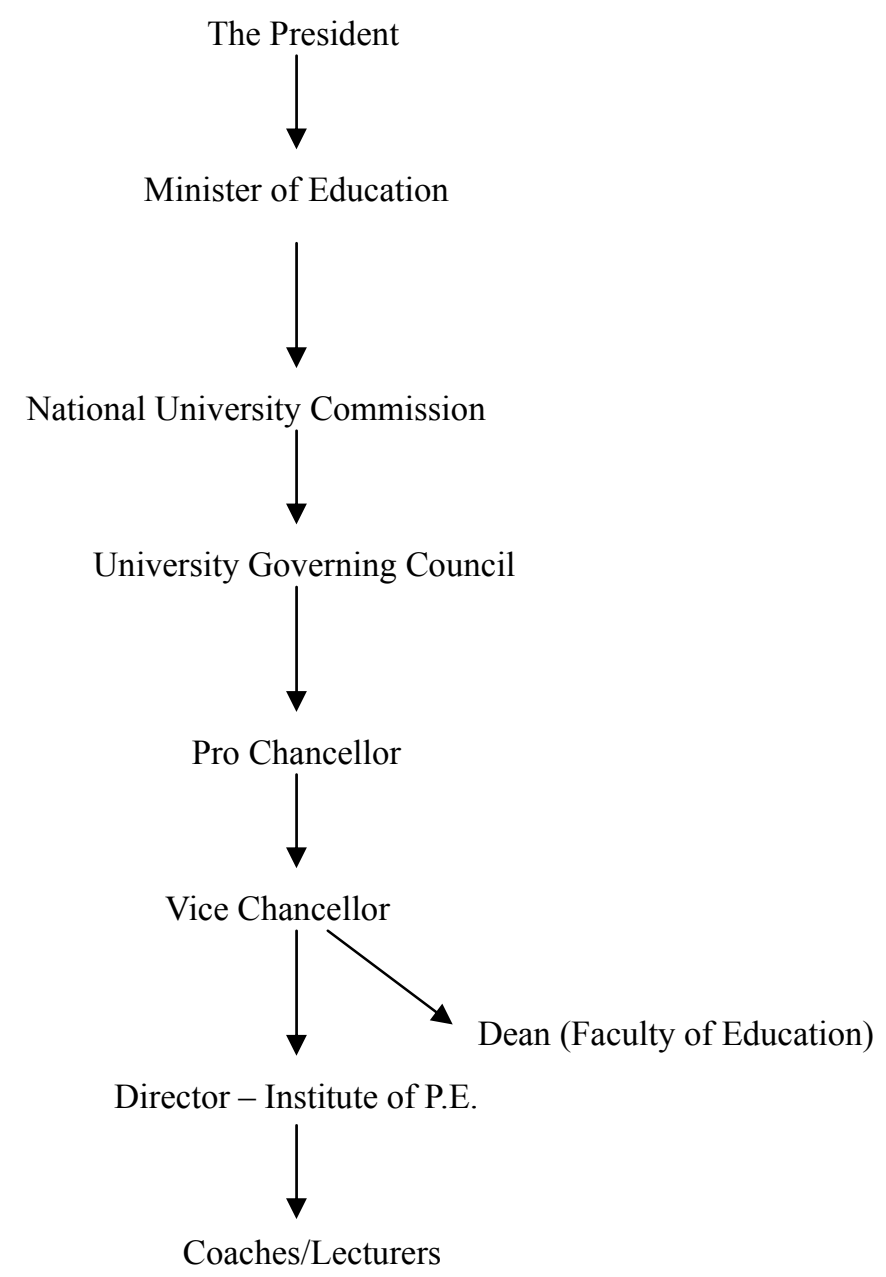

Figure 3. Proposed Organization Structure for College/ University P.E and Sports 


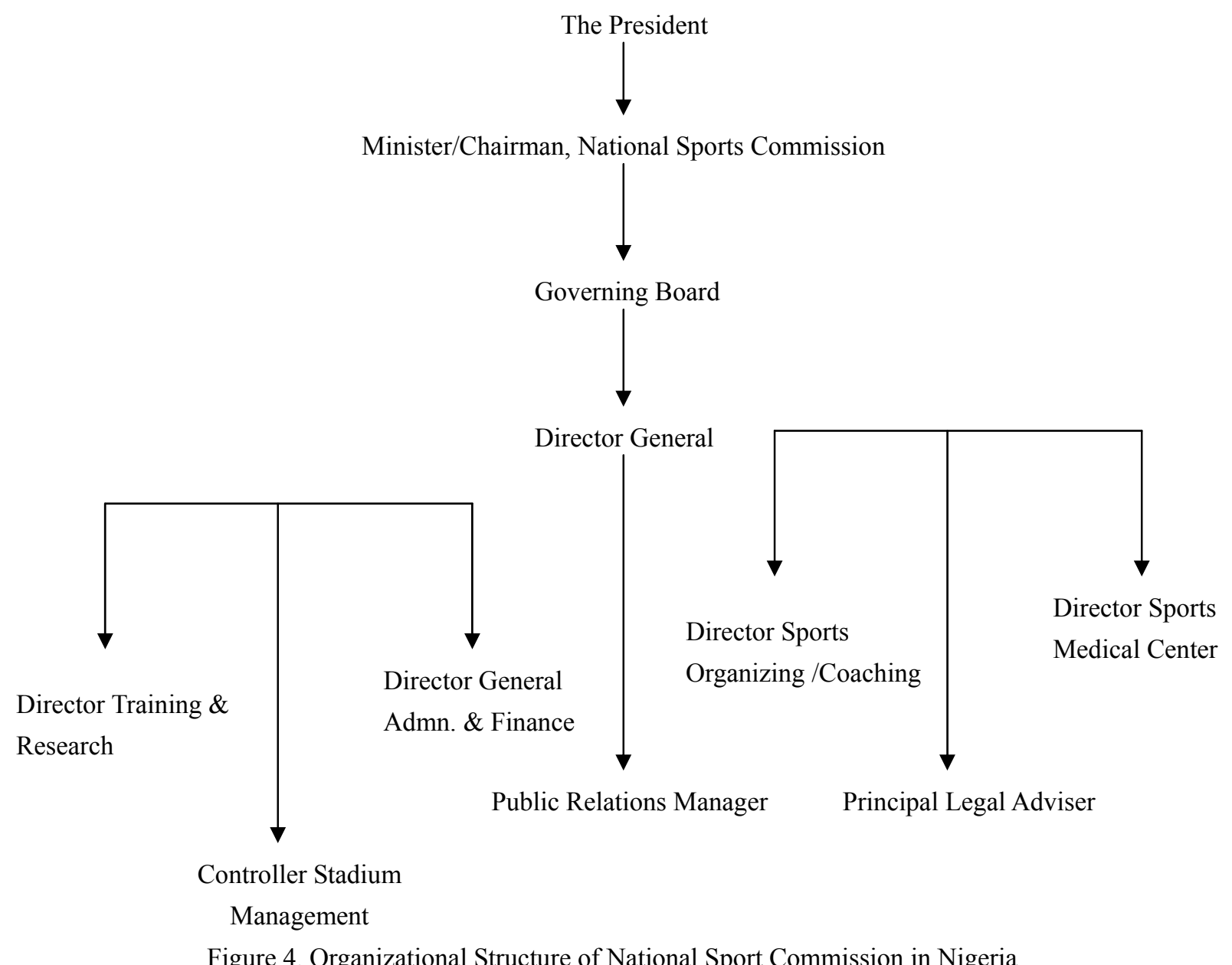

Figure 4. Organizational Structure of National Sport Commission in Nigeria 